\title{
Article \\ Enterotoxin Gene Distribution and Genotypes of Bacillus cereus sensu lato Isolated from Cassava Starch
}

\author{
Jennifer Sánchez-Chica ${ }^{1}$, Margarita M. Correa ${ }^{1} \mathbb{D}$, Angel E. Aceves-Diez ${ }^{2} \mathbb{D}$ \\ and Laura M. Castañeda-Sandoval ${ }^{1, *(\mathbb{D})}$ \\ 1 Grupo de Microbiología Molecular, Escuela de Microbiología, Universidad de Antioquia UdeA, \\ Calle 70 No. 52-21, Medellín 050010, Colombia; jennifer.sanchez@udea.edu.co (J.S.-C.); \\ margarita.correao@udea.edu.co (M.M.C.) \\ 2 Research and Development Department, Minkab Laboratories, Av. 18 de Marzo No. 546, Col. La Nogalera, \\ Guadalajara P.O. Box 44470, Jalisco, Mexico; aea@minkab.com \\ * Correspondence: laura.castaneda@udea.edu.co; Tel.: +57-4-219-5492
}

Citation: Sánchez-Chica, J.; Correa, M.M.; Aceves-Diez, A.E.; Castañeda-Sandoval, L.M. Enterotoxin Gene Distribution and Genotypes of Bacillus cereus sensu lato Isolated from Cassava Starch. Toxins 2021, 13, 131. https://doi.org/ $10.3390 /$ toxins 13020131

Received: 16 December 2020

Accepted: 21 January 2021

Published: 10 February 2021

Publisher's Note: MDPI stays neutral with regard to jurisdictional claims in published maps and institutional affiliations.

Copyright: (c) 2021 by the authors. Licensee MDPI, Basel, Switzerland. This article is an open access article distributed under the terms and conditions of the Creative Commons Attribution (CC BY) license (https:// creativecommons.org/licenses/by/ $4.0 /)$.

\begin{abstract}
Bacillus cereus is a human pathogenic bacterium found in foods with the potential to cause emesis and diarrhea. This study estimated the presence, toxigenic and genomic diversity of B. cereus s.l. obtained from cassava starch samples collected in bakeries and powdered food companies in Medellín (Colombia). Bacillus cereus s.l. was found in 43 of 75 (57\%) cassava starch samples and 98 isolates were obtained. The nhe $A B C, h b l C D A B, c y t K 2$, entFM and ces $B$ toxin genes were detected by multiplex PCR and the most frequent operon was $n h e A B C$, whereas ces $B$ gene was not found. Twelve toxigenic profiles were determined by the detection of toxin genes, and the most frequent profiles harbored all enterotoxin genes. A broad genomic diversity was detected according to $\mathrm{GTG}_{5}$-PCR fingerprinting results with 76 B. cereus s.l. grouped in sixteen clusters and the 22 isolates clustering separately. No relationship was observed between genomic background and toxigenic profiles. In general, the results showed a high genomic and enterotoxigenic diversity in B. cereus s.l. found in cassava starch. These results should incentive future studies to understand the distribution of B. cereus s.l. isolated on raw materials in comparison with finished products.
\end{abstract}

Keywords: cassava starch; Bacillus cereus; enterotoxin; emetic toxin; toxigenic diversity; genomic heterogeneity

Key Contribution: Bacillus cereus s.l. was detected in 57\% of cassava starch samples. Exclusively enterotoxigenic profiles were identified in the B. cereus s.l. A broad genomic heterogeneity was observed in the B. cereus s.l.

\section{Introduction}

Bacillus cereus sensu lato (s.l.) is a group of facultative anaerobic, spore-forming, Grampositive and motile rod bacteria ubiquitously distributed in the environment [1]. Eight members of the group are recognized, despite their high degree of genetic similarity: Bacillus anthracis, B. cereus sensu stricto (s.s.), Bacillus cytotoxicus, Bacillus mycoides, Bacillus pseudomycoides, Bacillus thuringiensis, Bacillus toyonensis and Bacillus weihenstephanensis [2]. In addition, new species have been proposed based on molecular analysis [3,4]. Some group species are recognized human pathogens [5]; they are naturally found in soil, which enables the contamination of food products and as their spores can survive high temperatures during the cooking processes, consumption of these products may lead to foodborne infection or intoxication [6].

Toxins produced by B. cereus cause two types of foodborne diseases in humans, the emetic and diarrheal syndromes [7]. The cereulide toxin causes emesis and it is produced by a non-ribosomal peptide synthetase encoded by the cereulide synthetase (ces) gene cluster, located on a megaplasmid [8]. Cereulide is active over a broad $\mathrm{pH}$ range (2 to 11), highly 
heat-stable $\left(121^{\circ} \mathrm{C}\right.$ for $\left.90 \mathrm{~min}\right)$ and is produced by B. cereus during the stationary phase of growth and under prolonged contaminated food storage [9]. This toxin triggers vacuole formation in cultured HEp-2 and HeLa cells and causes swelling of pig spermatozoa heads, impeding motility [9]. The diarrheal syndrome is produced after colonization of the small intestine by B. cereus. At this site, one or more enterotoxins, as the hemolysin BL (HBL), non-hemolytic enterotoxin (NHE) and/or cytotoxin K (CytK), induce diarrhea by stimulating the cAMP system and forming pores in the membrane of epithelial cells [9]. HBL is formed by two lytic proteins, $\mathrm{L} 2$ and L1, and a binding protein $\mathrm{B}$, these proteins are encoded by $h b l C, h b l D$ and $h b l A$ genes, respectively, which compose the $h b l C D A$ operon; in addition, some $B$. cereus strains carry the $h b l B$ gene, considered a pseudogene ( $h b l C D A B$ operon) [7]. NHE is formed by a cytolytic protein, NheA and two binding proteins, NheB and NheC, encoded by nheA, nheB and nhe C genes, respectively (nheABC operon) [10]. CytK is encoded by the $c y t K$ gene which has two variants; cytK1 encodes the CytK1 most toxic variant, while cytK2 encodes the less toxic and most common variant [7]. Most $B$. cereus strains involved in food-poisoning outbreaks are potential producers of enterotoxin FM (EntFM), encoded by the entFM gene, however, there is no evidence that this enterotoxin causes food-poisoning outbreaks [9].

Studies on the presence, genomic and toxigenic heterogeneity of $B$. cereus isolates provide relevant data on their clinical significance, the discovery of contamination sources and help in tracking isolates along the food chain [6]. Various works around the world have reported a high genomic diversity on B. cereus s.l. from foods such as ready-to-eat $[11,12]$ and powdered products [13], milk [6,14] and others [15], as well as a broad distribution of toxin genes in B. cereus s.l. isolated from foods. For example, in countries as Belgium [11], Brazil [16], Korea [17] and Thailand [18], most B. cereus isolates showed presence of all enterotoxin genes. In Colombia, B. cereus s.l. isolated from powdered foods [13] and ready-to-eat foods [12] contained the genes for enterotoxins production. Also, a previous study reported the detection of B. cereus s.l. toxin genes in DNA extracted directly from cassava starch [19]. Cassava is a tuberous edible plant from the American tropics [20], and in Colombia, the starch derived from cassava is frequently used for cooking a variety of foods including biscuits, soups and prepared meats such as sausages. Usually, cassava starch production is handcrafted, during the process this flour is air-dried on plastic tarps placed on the ground [21], which exposes the product to contamination by microorganisms in the soil, one of them is B. cereus s.l. Therefore, the objective of this research was to determine the presence and toxigenic and genomic heterogeneity of B. cereus s.l. isolated from cassava starch in Medellín (Colombia).

\section{Results}

\subsection{Detection of B. cereus s.l. on Cassava Starch}

A total of 43 of 75 (57\%) cassava starch samples were found contaminated by B. cereus s.l. These positive samples were collected in 10 bakeries of 12 sampled and in one powderedfoods company (designated A to M, Table 1) of Medellín (Colombia). Each of the sampling sites were selected to cover the north $(A, K, L)$, south $(J, H)$, east $(M, G)$, west $(B, E, I)$ and center $(\mathrm{C}, \mathrm{D}, \mathrm{F})$ of the city. The cassava starch suppliers differed for each bakery. By biochemical tests, 98 isolates were confirmed as B. cereus s.l. All positive cassava starch samples presented B. cereus s.l. counts equal or lower than $1 \times 10^{3} \mathrm{UFC}^{-1}$.

\subsection{Bacillus cereus s.l. Toxigenic Profiles}

Toxigenic determination of the 98 B. cereus s.l. from cassava starch by the three multiplex PCR (mPCR) assays showed that 97 isolates harbored all genes of $n$ heABC operon $(99 \%)$, cytK2 gene was found in 83 isolates $(85 \%)$, the $h b l C D A B$ operon in $77(79 \%)$ and entFM gene in $74(76 \%)$ isolates. The $h b l C D A$ operon lacking the $h b l B$ pseudogene was detected in 13 isolates (13\%) and none of the isolates contained the cesB gene (Figure 1). 
Table 1. Distribution of B. cereus s.l. obtained from cassava starch according to the sampling place.

\begin{tabular}{|c|c|c|c|c|}
\hline Place & Type & $\begin{array}{c}\text { Collected } \\
\text { Samples }(n)\end{array}$ & $\begin{array}{c}\text { Positive } \\
\text { Samples }(n)\end{array}$ & B. cereus s.l. (n) \\
\hline A & Bakery & 3 & 1 & 1 \\
\hline B & Bakery & 4 & 3 & 9 \\
\hline $\mathrm{C}$ & Bakery & 1 & 1 & 4 \\
\hline $\mathrm{D}$ & Bakery & 1 & 1 & 1 \\
\hline $\mathrm{E}$ & Bakery & 14 & 9 & 14 \\
\hline $\mathrm{F}$ & Bakery & 9 & 2 & 7 \\
\hline G & Bakery & 1 & 1 & 1 \\
\hline $\mathrm{H}$ & $\begin{array}{l}\text { Powdered foods } \\
\text { company }\end{array}$ & 14 & 13 & 34 \\
\hline I & Bakery & 10 & 5 & 13 \\
\hline $\mathrm{J}$ & Bakery & 11 & 3 & 6 \\
\hline $\mathrm{K}$ & Bakery & 5 & 4 & 8 \\
\hline $\mathrm{L}$ & Bakery & 1 & 0 & 0 \\
\hline $\mathrm{M}$ & Bakery & 1 & 0 & 0 \\
\hline TOTAL & & 75 & 43 & 98 \\
\hline
\end{tabular}

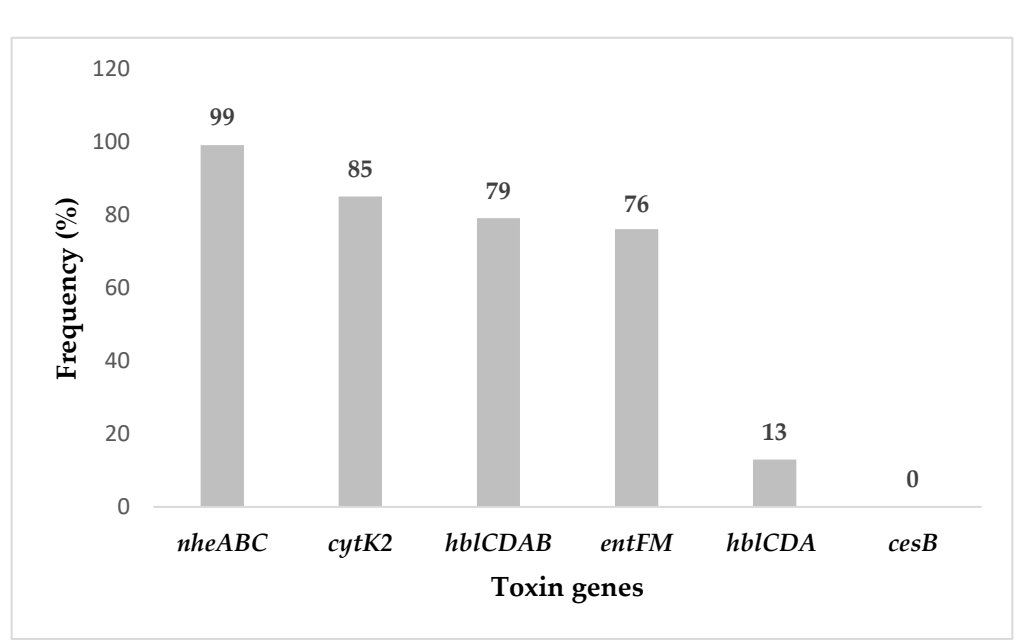

Figure 1. Distribution of toxin genes. Frequency of toxin genes in B. cereus s.l. isolated from cassava starch.

In total, twelve toxigenic profiles were determined according to toxin genes detection (Table 2). Most of the B. cereus s.l. (58\%) carried profiles with all genes for NHE, HBL, CytK2 and EntFM production (profiles I and II), whereas $21 \%$ of the isolates contained the genes for NHE, HBL and CytK2 (profiles III and IV) and 10\% of the isolates harbored the genes for NHE, HBL and EntFM (profiles V and VI). Therefore, $58 \%$ of B. cereus s.l. had the genetic capacity to potentially produce four toxins (profiles I and II), 35\% harbored all genes to produce three different toxins (profiles III to VII), $5 \%$ had genes for two toxins (profiles VIII to XI) and one isolate had the genes for the NHE enterotoxin exclusively (profile XII).

\subsection{Genotyping of B. cereus s.l.}

The genotyping of 98 B. cereus s.l. isolated from cassava starch using (GTG) $)_{5}-\mathrm{PCR}$ fingerprinting showed that sixteen clusters were formed by 76 B. cereus s.l. isolates and 22 isolates clustered separately (Figure 2). A large diversity was observed on clusters 5 , 7 and 8 , which were composed by isolates from at less four sampling places and three toxigenic profiles (Figures 2 and 3). In contrast, clusters 1, 2, 4 and 14 each contained isolates from a single sampling place. Interestingly, clusters 12 and 13 contained isolates from different sampling places but had the same toxigenic profile. Regarding toxigenic profiles and genetic clusters, 10 of 12 toxigenic profiles were distributed in the sixteen genetic clusters while toxigenic profiles IX and XII were exclusive of isolates clustered individually. 
Table 2. Toxigenic profiles of 98 B. cereus s.l. obtained from cassava starch.

\begin{tabular}{ccc}
\hline Profile & Toxin Genes & Number of B. cereus s.l. (\%) \\
\hline I & $n h e A B C, h b l C D A B, c y t K 2$, entFM & $49(50)$ \\
II & $n h e A B C, h b l C D A, c y t K 2$, entFM & $8(8)$ \\
III & $n h e A B C, h b l C D A B$, cytK2 & $19(20)$ \\
IV & $n h e A B C, h b l C D A$, cytK2 & $1(1)$ \\
V & $n h e A B C, h b l C D A B$, entFM & $8(8)$ \\
VI & $n h e A B C$, hblCDA, entFM & $2(2)$ \\
VII & $n h e A B C$, cytK2, entFM & $5(5)$ \\
VIII & $n h e A B C$, cytK2 & $1(1)$ \\
IX & $n h e A B C, h b l C D A$ & $2(2)$ \\
X & $n h e A B C$, entFM & $1(1)$ \\
XI & $h b l C D A B$, entFM & $1(1)$ \\
XII & $n h e A B C$ & $1(1)$ \\
\hline
\end{tabular}

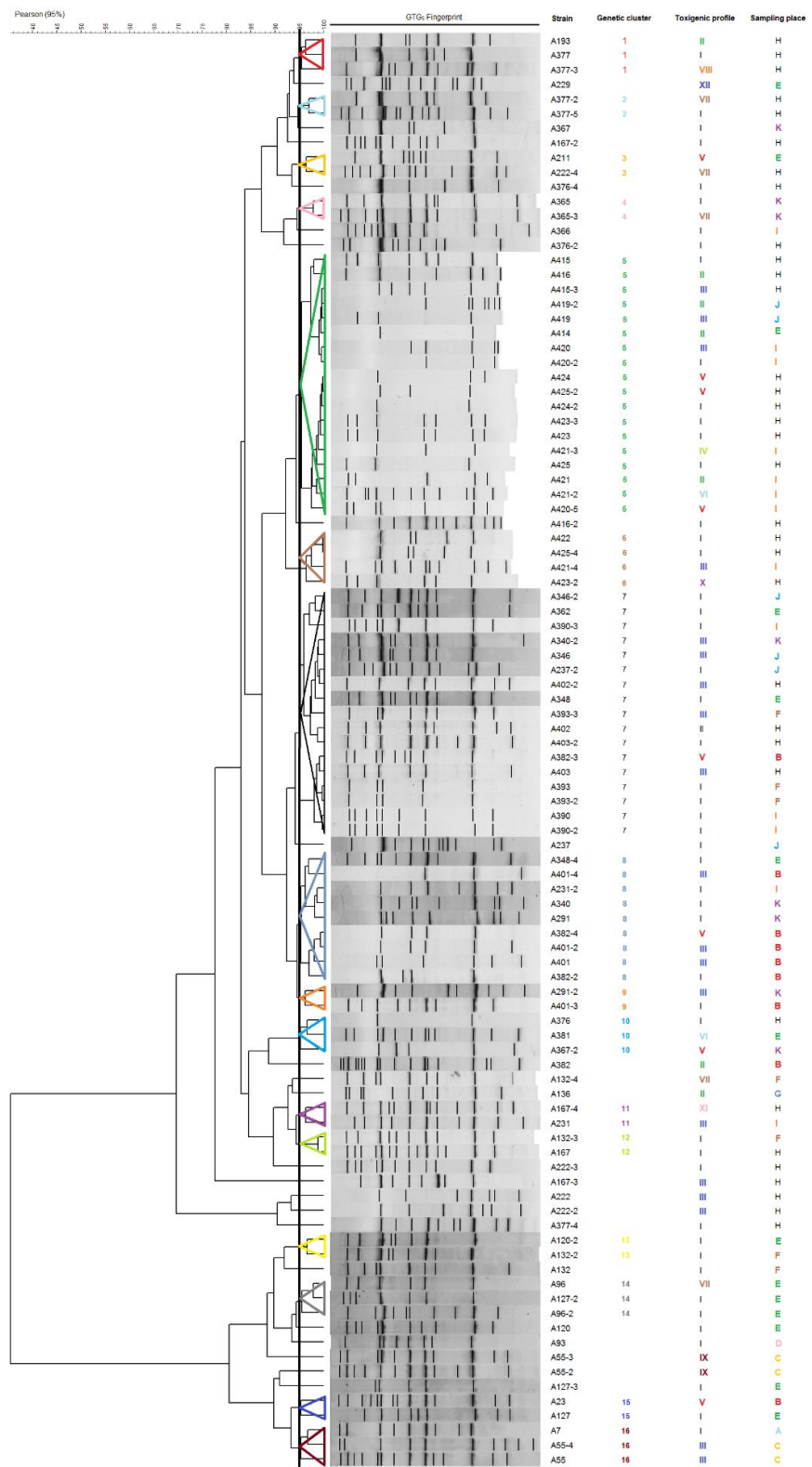

Figure 2. Genotyping of the B. cereus s.l. obtained from cassava starch. Dendrogram of (GTG) ${ }_{5}^{-}$ PCR fingerprints according to Pearson correlation coefficient (95\%) and UPGMA. Colors represent different clusters, toxigenic profiles and sampling places. 


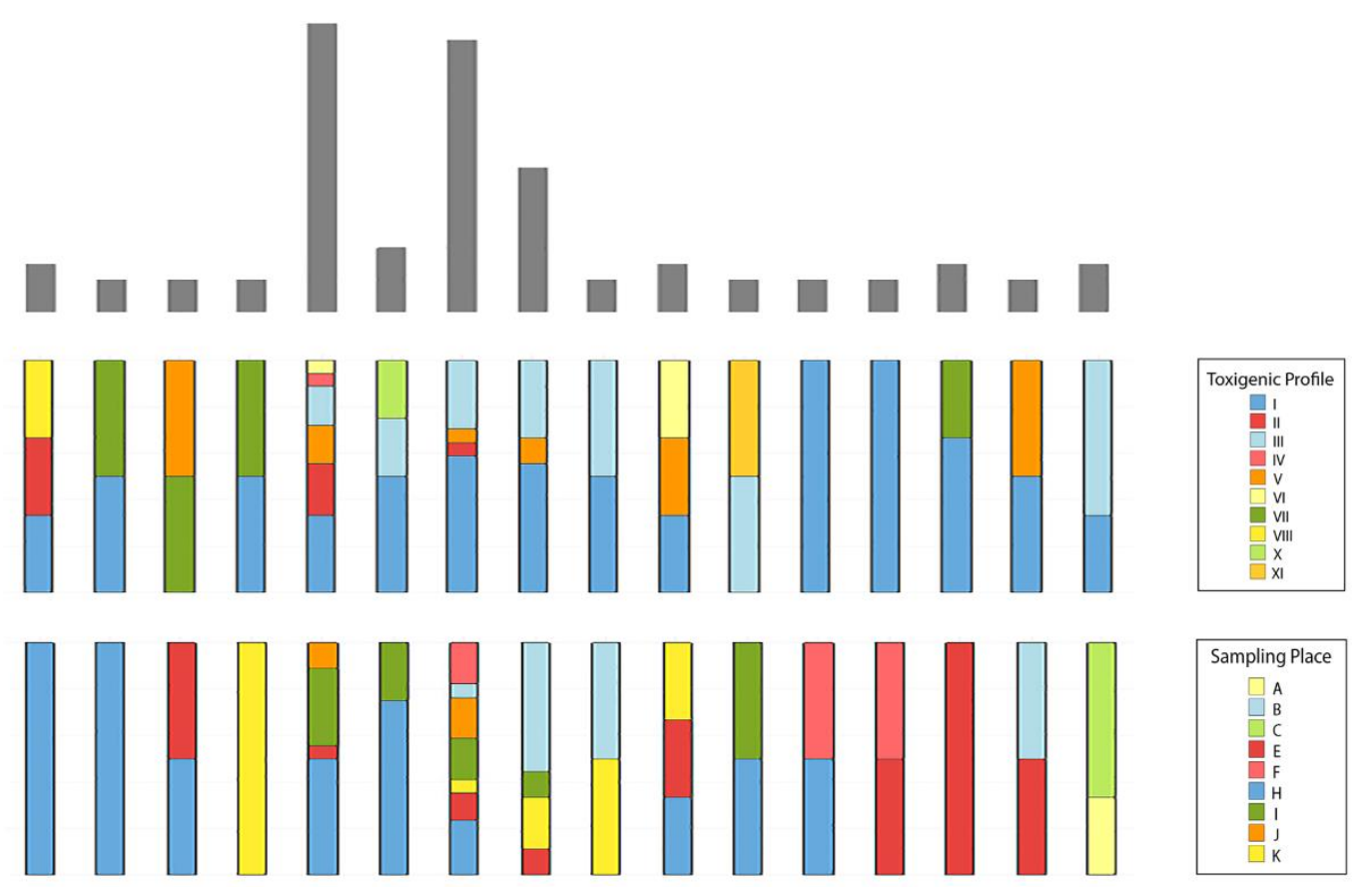

Figure 3. Relationship among genetic cluster, toxigenic profile and sampling place. Each column represents a genetic cluster. The superior bars in grey indicate the number of B. cereus s.l. isolates, while the different colors in the bars represent the frequency of toxigenic profile and sampling place, according to the legend.

\section{Discussion}

Bacillus cereus s.l. was detected in 43 of 75 (57\%) cassava starch samples. This is considered a relatively high incidence if compared to values obtained during the analysis of other food matrices in Colombia such as powdered foods that showed incidences from $10 \%$ to $13 \%$ [13]. Possibly, the high presence of B. cereus s.l. in the cassava starch is a consequence of its handcrafted manufacturing process, in which flour contamination with $B$. cereus occurs during the drying of the flour on plastic tarps placed on the ground under the sun, in an open-air environment. Besides, the basic microbiological analysis of this food matrix which comprises testing for fungi, yeast, total aerobic mesophilic bacteria and Escherichia coli, it does not include detecting B. cereus s.l., which impedes a better control of this pathogenic bacterium in the cassava starch [22]. Worldwide, incidences of $B$. cereus s.l. are variable; the values reported are either higher or lower than the ones obtained in this study; however, as long as the food raw-materials and flours are handcrafted and slightly processed, they are susceptible to contamination by $B$. cereus spores and vegetative cells, constituting great risk for human health $[12,13]$. Studies performed in countries such as Korea found B. cereus in $40 \%$ of raw rice samples [23]; in Iran, $42 \%$ of infant formula analyzed carried B. cereus [24] and in New Zealand, B. cereus incidences in dehydrated potato ranged from $10 \%$ to $40 \%$ [25]. In Belgium, variable incidences of B. cereus s.l. (5\% to $100 \%$ ) were informed in ready-to-eat foods [11], and, in Scotland, reports of this pathogen varied from $20 \%$ to $88 \%$ in soil, feces and vegetables samples [26]. In this work, all positive cassava starch samples presented B. cereus s.l. counts equal or lower than $1 \times 10^{3} \mathrm{UFC}^{-1}$, and although, these amounts are considered safe for human consumption [27], similar $B$. cereus counts have been found in foods causing disease [7]. Considering that eleven of thirteen sampling places presented cassava starch samples contaminated by B. cereus s.l., it is recommended to maintain high baking temperatures for products using cassava starch as the raw material, this with the aim of eliminating B. cereus s.l. spores and vegetative cells in the finished product.

The enterotoxin genes showed a broad distribution in the B. cereus s.l. isolated from cassava starch. Mainly, the $n h e A B C$ operon was detected among the isolates $(99 \%)$, carrying 
all three genes for the non-hemolytic enterotoxin production. This finding is common to those from studies in Brazil [16], Korea [28] and Thailand [18], which have informed that $B$. cereus isolated from foods and soil harbored all genes of the nhe $A B C$ operon. Furthermore, bioinformatic analyses suggested that the nhe $A B C$ operon is highly conserved in $B$. cereus s.l. strains, mainly because of the vertical inheritance; but it is not clear yet if this operon has an additional biological function [29]. The cytK2 gene was detected in $85 \%$ of B. cereus s.l. Similar frequencies of this gene were observed for B. cereus s.l. strains isolated from powdered foods in Colombia, with a $62 \%$ occurrence of cytK2 [13]. The B. cereus s.l. isolated from cassava starch samples showed a high frequency of cytK2 gene, but the frequencies generally reported (45\% to $89 \%)$ [11,16,18,30], denote that cytK2 is broadly distributed among B. cereus s.l.

The $h b l C D A$ operon was found in 90 B. cereus s.l. $(92 \%)$, from which 77 isolates $(85 \%)$ harbored the $h b l B$ pseudogene. These isolates with $h b l C D A$ operon carry all genes that should encode an active hemolysin BL. Some studies report that B. cereus s.l. isolates from foods may present polymorphisms in the $h b l C D A$ operon, as reflected by the lack of one or two operon components $[13,17,31]$. The frequencies on $B$. cereus carrying $h b l C D A$ operon genes highly vary among countries and samples evaluated. Frequencies as high as $84 \%$ to $100 \%$ have been reported in studies performed in Belgium [11] and Korea [28]; whereas lower frequencies (50\% to 70\%) were reported in Denmark [32] and Brazil [16]. Furthermore, in this study, the entFM gene was detected in 74 isolates (76\%). This result agrees with previous studies showing high frequencies of entFM gene in B. cereus s.l. $[17,24,33,34]$.

None of the 98 B. cereus s.l. isolated from cassava starch harbored the ces $B$ gene. The no detection of presumptive emetic strains in this study is probably due to the low frequency of these strains that belong to a special lineage of B. cereus s.s. [35]. It is suggested that the use Bacara agar could improve the isolation of emetic $B$. cereus strains given that this medium is more selective than MYP because it impedes the growth of other Gram-positive microorganisms commonly found in foods [36]; therefore, future studies should incorporate this agar to see if the detection of emetic strains is improved. These emetic strains contain the megaplasmid that harbors the cereulide synthetase (ces) gene cluster [35] and according to biochemical and molecular test, share various phenotypic and genotypic characteristics that include, hydrolysis of starch and salicin, haemolytic activity, and genotypic/protein patterns in assays such as random amplification of polymorphic DNA (RAPD), multilocus sequence typing (MLST), phenetic Fourier transform Infrared (FTIR) and protein profiling [37]. Studies in countries such as Belgium [11], Brazil [16] and China [38] have reported low frequency of emetic strains, or they are even not detected. Meanwhile, in Asian countries, e.g., Korea, B. cereus emetic strains have been detected in rice [28]. In general, the finding of emetic strains mainly in oriental rice dishes could indicate a relationship between $B$. cereus emetic strains and rice [5].

According to the detection of the toxin genes nhe $A B C, h b l C D A B$, cytK2, entFM and ces $B$, twelve different toxigenic profiles were identified. The majority of the B. cereus s.l. isolates $(58 \%)$ carried profiles with all genes for NHE, HBL, CytK2 and EntFM production (profiles I and II). This result resembles those obtained in other countries such as Belgium [11], Brazil [16], Korea [17] and Thailand [18], where the most frequent profiles harbored all enterotoxin genes in B. cereus isolated from foods. In addition, in a previous study performed in Colombia that evaluated the toxin genes of B. cereus s.l. isolated from flours and powdered milk, found that the most frequent toxigenic profile included all enterotoxin genes. Altogether, the results reinforce the high degree of conservation of enterotoxin genes in B. cereus s.l. strains isolated from powdered food and other matrices [13]. Furthermore, the data suggest that the B. cereus s.l. isolated from cassava starch are potentially able to cause just the diarrheal syndrome, but further studies directed to detect the levels and simultaneity of expression of all toxins will indicate if they have the potential to cause foodborne illness.

Genotyping by (GTG) 5 -PCR fingerprinting of the B. cereus s.l. isolated from cassava starch showed a high diversity. According to sampling places or toxigenic profiles, the 
respective isolates get distributed on various clusters. In general, no association was found between clusters and collection places; however, clusters 1, 2, 4 and 14, each contained isolates from a single sampling place, which may indicate particular contaminant strains in these places. In addition, clusters 12 and 13 exclusively contained isolates of toxigenic profile I, but from various collection places (E, F and $\mathrm{H}$ ) and cassava starch suppliers. All toxigenic profiles, except IX and XII, were spread among the different clusters, whereby, $B$. cereus s.l. isolates carrying the same toxigenic profile presented different banding patterns and all clusters, except clusters 12 and 13, presented different toxigenic profiles. These results suggest that there is no relationship between genetic background and toxigenic profiles, as previously reported $[13,15,16]$.

In general, the results of this study indicate that B. cereus s.l. isolates obtained from cassava starch have the potential to cause diarrheal-type foodborne illness; this given the fact that the isolates harbor the genes codifying for the HBL, NHE and CytK2 toxins. The B. cereus s.l. genotyping revealed a high genomic heterogeneity among the isolates; this and the high number of toxigenic profiles detected, suggest the presence of different species of B. cereus group, as Bacillus cytotoxicus, Bacillus mycoides, Bacillus pseudomycoides, Bacillus thuringiensis, and Bacillus weihenstephanensis, among the isolates, whereby further studies are needed to confirm it and to characterize the species. This study provides useful information for the assessment of the potential risk of the cassava starch samples containing this pathogen to cause foodborne illness; in addition, it could help to a better comprehension of the epidemiology of B. cereus s.l. in this raw material. Finally, these results should incentive additional studies to understand the distribution of B. cereus s.l. on raw materials as cassava starch, compared to finished food products and to encourage health politics for the microbiological control of B. cereus s.l. in raw materials used for manufacturing traditional Colombian foods.

\section{Materials and Methods}

\subsection{Cassava Starch Samples and B. cereus s.l. Isolation}

A total of 75 cassava starch samples were randomly collected in twelve bakeries and one powdered-foods company of Medellín (Colombia). Isolation of B. cereus s.l. from cassava starch was done according to the ISO 7932:2004 norm for the enumeration of presumptive $B$. cereus cells [27]. Concisely, $225 \mathrm{~mL}$ of peptone water was used to dissolve $25 \mathrm{~g}$ of cassava starch and serial dilutions were carried out until $10^{-3}$, and $100 \mu \mathrm{L}$ of each dilution was spread on mannitol egg yolk polymyxin agar (MYP) (Merck Millipore, Darmstadt, Germany); and the MYP plates were incubated at $37^{\circ} \mathrm{C}$ for at least $48 \mathrm{~h}$. According to the norm, five presumptive colonies of each cassava starch sample were analyzed using biochemical tests following standard protocols [27]. Biochemical test included catalase, motility, Voges-Proskauer reaction, glucose, xylose and arabinose utilization, $\beta$-hemolytic activity and, starch, casein and gelatin hydrolysis. The confirmed B. cereus s.l. isolates were conserved in Tryptic Soy Broth and 15\% (v/v) glycerol and stored at $-80{ }^{\circ} \mathrm{C}$. Some reference strains (B. cereus NVH 1257, F4810/72, ATCC 14579 and ATCC 10987) served as positive controls for biochemical test and molecular analysis.

\subsection{B. cereus s.l. Toxin Genes Detection}

For DNA extraction, B. cereus s.l. isolates and B. cereus reference strains were grown in Luria-Bertani (LB) broth (Difco, Detroit, MI, USA), incubated overnight at $37^{\circ} \mathrm{C}$. DNA extraction was performed according to previously described methodology [39]. The detection of $n h e A B C, h b l C D A B, c y t K 2$, entFM and $c e s B$ toxin genes was done by three multiplex PCR assays as previously described [12].

\subsection{Bacillus cereus s.l. (GTG) $)_{5}$ PCR Fingerprinting}

The genomic heterogeneity of B. cereus s.l. isolated from cassava starch was evaluated by repetitive element palindromic-polymerase chain reaction (rep-PCR) using (GTG) 5 primer, as described previously [13]. Briefly, the $20 \mu \mathrm{L}$ reaction contained $0.6 \mu \mathrm{M}$ of $(\mathrm{GTG})_{5}$ 
primer, $200 \mu \mathrm{M}$ of dNTPs mix, $3.5 \mathrm{mM}$ of $\mathrm{MgCl}_{2}, 1.6 \mathrm{U}$ of Taq DNA polymerase (Thermo Fisher Scientific, Waltham, MA, USA ), $2 \mu \mathrm{L}$ of 10X PCR buffer and $50 \mathrm{ng}$ of DNA template. PCR consisted of, an initial denaturation of $5 \mathrm{~min}$ at $94{ }^{\circ} \mathrm{C}$, followed by 30 cycles of denaturation at $94{ }^{\circ} \mathrm{C}$ for $1 \mathrm{~min}$, annealing at $45^{\circ} \mathrm{C}$ for $1 \mathrm{~min}$ and elongation at $65^{\circ} \mathrm{C}$ for $8 \mathrm{~min}$, and a final extension at $65^{\circ} \mathrm{C}$ for $16 \mathrm{~min}$. PCR products were electrophoresed in a multiSUB Choice electrophoresis system (Cleaver Scientific, Warwickshire, UK), with a $15 \times 15 \mathrm{~cm}$ gel tray, $1.5 \%(w / v)$ agarose gel (Amresco, Solon, OH, USA), with ethidium bromide for $2.5 \mathrm{~h}$, at a constant voltage of $120 \mathrm{~V}$ in $1 \mathrm{X}$ TBE buffer, at $4{ }^{\circ} \mathrm{C}$. The gene ruler $1 \mathrm{~Kb}$ DNA ladder (Thermo Fisher Scientific, Waltham, MA, USA) was used as a size standard. The resulting fingerprints were analyzed using the BioNumerics 6.6 software package (Applied Maths Inc., St Martems, Belgium), with 1\% optimization and 1\% position tolerance. The Pearson correlation coefficient (95\%) and the unweighted pair group method with arithmetic average (UPGMA) were used to obtain a dendrogram of the profiles for cluster analysis.

Author Contributions: Conceptualization, J.S.-C., M.M.C., A.E.A.-D. and L.M.C.-S.; methodology, J.S.-C., M.M.C., A.E.A.-D. and L.M.C.-S.; software, J.S.-C.; validation, J.S.-C., M.M.C., A.E.A.-D. and L.M.C.-S.; formal analysis, J.S.-C., M.M.C., A.E.A.-D. and L.M.C.-S.; investigation, J.S.-C. and L.M.C.-S.; resources, M.M.C. and L.M.C.-S.; data curation, J.S.-C. and L.M.C.-S.; writing-original draft preparation, J.S.-C.; writing-review and editing, J.S.-C., M.M.C., A.E.A.-D. and L.M.C.-S.; visualization, J.S.-C., M.M.C., A.E.A.-D. and L.M.C.-S.; supervision, L.M.C.-S.; project administration, L.M.C.-S.; funding acquisition, M.M.C. and L.M.C.-S. All authors have read and agreed to the published version of the manuscript.

Funding: This research was funded by the Department of Science, Technology and InnovationColciencias-grant number 386-2011.

Data Availability Statement: The data presented in this study are available upon request to the corresponding author. The data are not publicly available at this moment because the doctoral candidate Jennifer Sánchez-Chica is in the process of thesis defense. Subsequently, it will be delivered to the public repository of the University of Antioquia, where the data will be publicly available.

Conflicts of Interest: The authors declare no conflict of interest.

\section{References}

1. Ceuppens, S.; Boon, N.; Uyttendaele, M. Diversity of Bacillus cereus group strains is reflected in their broad range of pathogenicity and diverse ecological lifestyles. FEMS Microbiol. Ecol. 2013, 84, 433-450. [CrossRef]

2. Ehling-Schulz, M.; Koehler, T.M. The Bacillus cereus Group: Bacillus species with Pathogenic Potential. Microbiol. Spec. 2019, 7. [CrossRef]

3. Miller, R.A.; Beno, S.M.; Kent, D.J.; Carroll, L.M.; Martin, N.H.; Boor, K.J.; Kovac, J. Bacillus wiedmannii sp. nov., a psychrotolerant and cytotoxic Bacillus cereus group species isolated from dairy foods and dairy environments. Int. J. Syst. Evol. Microbiol. 2016, 66, 4744-4753. [CrossRef]

4. Liu, Y.; Du, J.; Lai, Q.; Zeng, R.; Ye, D.; Xu, J.; Shao, Z. Proposal of nine novel species of the Bacillus cereus group. Int. J. Syst. Evol. Microbiol. 2017, 67, 2499-2508. [CrossRef] [PubMed]

5. Logan, N.A. Bacillus and relatives in foodborne illness. J. Appl. Microbiol. 2012, 112, 417-429. [CrossRef] [PubMed]

6. De Jonghe, V.; Coorevits, A.; Vandroemme, J.; Heyrman, J.; Herman, L.; De Vos, P.; Heyndrickx, M. Intraspecific genotypic diversity of Bacillus species from raw milk. Int. Dairy J. 2008, 18, 496-505. [CrossRef]

7. Stenfors Arnesen, L.P.; Fagerlund, A.; Granum, P.E. From soil to gut: Bacillus cereus and its food poisoning toxins. FEMS Microbiol. Rev. 2008, 32, 579-606. [CrossRef] [PubMed]

8. Rajkovic, A.; Uyttendaele, M.; Vermeulen, A.; Andjelkovic, M.; Fitz-James, I.; In't Veld, P.; Denon, Q.; Vérhe, R.; Debevere, J. Heat resistance of Bacillus cereus emetic toxin, cereulide. Lett. Appl. Microbiol. 2008, 46, 536-541. [CrossRef]

9. Bhunia, A.K. Bacillus cereus and Bacillus anthracis. In Foodborne Microbial Pathogens; Springer: New York, NY, USA, 2007; pp. 135-148.

10. Fagerlund, A.; Lindbäck, T.; Storset, A.K.; Granum, P.E.; Hardy, S.P. Bacillus cereus Nhe is a pore-forming toxin with structural and functional properties similar to the ClyA (HlyE, SheA) family of haemolysins, able to induce osmotic lysis in epithelia. Microbiology 2008, 154, 693-704. [CrossRef]

11. Samapundo, S.; Heyndrickx, M.; Xhaferi, R.; Devlieghere, F. Incidence, diversity and toxin gene characteristics of Bacillus cereus group strains isolated from food products marketed in Belgium. Int. J. Food Microbiol. 2011, 150, 34-41. [CrossRef] 
12. Sánchez-Chica, J.; Correa, M.M.; Aceves-Diez, A.E.; Rasschaert, G.; Heyndrickx, M.; Castañeda-Sandoval, L.M. Genomic and Toxigenic Heterogeneity of Bacillus cereus sensu lato Isolated from Ready-to-Eat Foods and Powdered Milk in Day Care Centers in Colombia. Foodborne Pathog. Dis. 2020, 17, 340-347. [CrossRef] [PubMed]

13. Sánchez-Chica, J.; Correa, M.M.; Aceves-Diez, A.E.; Castañeda-Sandoval, L.M. Genetic and toxigenic diversity of Bacillus cereus group isolated from powdered foods. J. Food Sci. Technol. 2020. [CrossRef]

14. Gao, T.; Ding, Y.; Wu, Q.; Wang, J.; Zhang, J.; Yu, S.; Yu, P.; Liu, C.; Kong, L.; Feng, Z.; et al. Prevalence, Virulence Genes, Antimicrobial Susceptibility, and Genetic Diversity of Bacillus cereus Isolated From Pasteurized Milk in China. Front. Microbiol. 2018, 9, 533. [CrossRef] [PubMed]

15. Lee, N.; Sun, J.M.; Kwon, K.Y.; Kim, H.J.; Koo, M.; Chun, H.S. Genetic diversity, antimicrobial resistance, and toxigenic profiles of Bacillus cereus strains isolated from sunsik. J. Food Prot. 2012, 75, 225-230. [CrossRef] [PubMed]

16. Chaves, J.Q.; Pires, E.S.; Vivoni, A.M. Genetic diversity, antimicrobial resistance and toxigenic profiles of Bacillus cereus isolated from food in Brazil over three decades. Int. J. Food Microbiol. 2011, 147, 12-16. [CrossRef]

17. Kim, S.K.; Kim, K.P.; Jang, S.S.; Shin, E.M.; Kim, M.J.; Oh, S.; Ryu, S. Prevalence and Toxigenic profiles of Bacillus cereus isolated from dried red peppers, rice, and sunsik in Korea. J. Food Prot. 2009, 72, 578-582. [CrossRef]

18. Ngamwongsatit, P.; Buasri, W.; Pianariyanon, P.; Pulsrikarn, C.; Ohba, M.; Assavanig, A.; Panbangred, W. Broad distribution of enterotoxin genes (hblCDA, nheABC, cytK, and entFM) among Bacillus thuringiensis and Bacillus cereus as shown by novel primers. Int. J. Food Microbiol. 2008, 121, 352-356. [CrossRef]

19. Sánchez-Chica, J.; Correa, M.M.; Aceves-Diez, A.E.; Castañeda-Sandoval, L.M. Direct detection of toxigenic Bacillus cereus in dietary complement for children and cassava starch. Rev. Colomb. Quim. 2014, 43, 5-9. [CrossRef]

20. Augustyn, A. Cassava. Available online: https://www.britannica.com/plant/cassava (accessed on 23 November 2020).

21. Arenas, F. 127 Usos Tiene la Yuca, Según Estudio de Corpoica en Espinal (Tolima)-Archivo Digital de Noticias de Colombia y el Mundo Desde 1.990-Eltiempo.com. Available online: https:/ / www.eltiempo.com/archivo/documento/CMS-3254363 (accessed on 10 August 2020).

22. Aristizábal, J.; Sánchez, T. Guía Técnica Para Producción y Análisis de Almidón de Yuca; Organización de las Naciones Unidas para la agricultura y la alimentación: Roma, Italia, 2007.

23. Jang, J.H.; Lee, N.A.; Woo, G.J.; Park, J. Prevalence of Bacillus cereus group in rice and distribution of enterotoxin genes. Food Sci. Biotechnol. 2006, 15, 232-237.

24. Rahimi, E.; Abdos, F.; Momtaz, H.; Torki Baghbadorani, Z.; Jalali, M. Bacillus cereus in infant foods: Prevalence study and distribution of enterotoxigenic virulence factors in Isfahan Province, Iran. Sci. World J. 2013, 2013, 292571. [CrossRef]

25. King, N.J.; Whyte, R.; Hudson, J.A. Presence and significance of Bacillus cereus in dehydrated potato products. J. Food Prot. 2007, 70, 514-520. [CrossRef] [PubMed]

26. Altayar, M.; Sutherland, A.D. Bacillus cereus is common in the environment but emetic toxin producing isolates are rare. J. Appl. Microbiol. 2006, 100, 7-14. [CrossRef] [PubMed]

27. International Organization for Standardization ISO 7932:2004. Microbiology of Food and Animal Feeding Stuffs—Horizontal Method for the Enumeration of Presumptive Bacillus Cereus—Colony-Count Technique at 30 Degrees C; ISO: Geneva, Switzerland, $2004 ;$ p. 13.

28. Kim, B.; Bang, J.; Kim, H.; Kim, Y.; Kim, B.S.; Beuchat, L.R.; Ryu, J.H. Bacillus cereus and Bacillus thuringiensis spores in Korean rice: Prevalence and toxin production as affected by production area and degree of milling. Food Microbiol. 2014, 42, 89-94. [CrossRef] [PubMed]

29. Böhm, M.E.; Huptas, C.; Krey, V.M.; Scherer, S. Massive horizontal gene transfer, strictly vertical inheritance and ancient duplications differentially shape the evolution of Bacillus cereus enterotoxin operons hbl, cytK and nhe. BMC Evol. Biol. 2015, 15. [CrossRef] [PubMed]

30. Guinebretière, M.H.; Broussolle, V.; Nguyen-The, C. Enterotoxigenic profiles of food-poisoning and food-borne Bacillus cereus strains. J. Clin. Microbiol. 2002, 40, 3053-3056. [CrossRef]

31. Wehrle, E.; Moravek, M.; Dietrich, R.; Bürk, C.; Didier, A.; Märtlbauer, E. Comparison of multiplex PCR, enzyme immunoassay and cell culture methods for the detection of enterotoxinogenic Bacillus cereus. J. Microbiol. Methods 2009, 78, 265-270. [CrossRef]

32. Hansen, B.M.; Hendriksen, N.B. Detection of enterotoxic Bacillus cereus and Bacillus thuringiensis: Strains by PCR analysis. Appl. Environ. Microbiol. 2001, 67, 185-189. [CrossRef]

33. Carter, L.; Chase, H.R.; Gieseker, C.M.; Hasbrouck, N.R.; Stine, C.B.; Khan, A.; Ewing-Peeples, L.J.; Tall, B.D.; Gopinath, G.R. Analysis of enterotoxigenic Bacillus cereus strains from dried foods using whole genome sequencing, multi-locus sequence analysis and toxin gene prevalence and distribution using endpoint PCR analysis. Int. J. Food Microbiol. 2018, 284, 31-39. [CrossRef]

34. Osman, K.M.; Kappell, A.D.; Orabi, A.; Al-Maary, K.S.; Mubarak, A.S.; Dawoud, T.M.; Hemeg, H.A.; Moussa, I.M.I.; Hessain, A.M.; Yousef, H.M.Y.; et al. Poultry and beef meat as potential seedbeds for antimicrobial resistant enterotoxigenic Bacillus species: A materializing epidemiological and potential severe health hazard. Sci. Rep. 2018, 8. [CrossRef]

35. Økstad, O.; Kolstø, A. Genomics of Bacillus species. In Genomics of Foodborne Bacterial Pathogens; Wiedmann, M., Zhang, W., Eds.; Springer: New York, NY, USA, 2011; pp. 29-53.

36. Carroll, L.M.; Wiedmann, M.; Mukherjee, M.; Nicholas, D.C.; Mingle, L.A.; Dumas, N.B.; Cole, J.A.; Kovac, J. Characterization of Emetic and Diarrheal Bacillus cereus Strains From a 2016 Foodborne Outbreak Using Whole-Genome Sequencing: Addressing the Microbiological, Epidemiological, and Bioinformatic Challenges. Front. Microbiol. 2019, 10, 144. [CrossRef] 
37. Ehling-Schulz, M.; Svensson, B.; Guinebretiere, M.H.; Lindbäck, T.; Andersson, M.; Schulz, A.; Fricker, M.; Christiansson, A.; Granum, P.E.; Märtlbauer, E.; et al. Emetic toxin formation of Bacillus cereus is restricted to a single evolutionary lineage of closely related strains. Microbiology 2005, 151, 183-197. [CrossRef] [PubMed]

38. Yu, S.; Yu, P.; Wang, J.; Li, C.; Guo, H.; Liu, C.; Kong, L.; Yu, L.; Wu, S.; Lei, T.; et al. A Study on Prevalence and Characterization of Bacillus cereus in Ready-to-Eat Foods in China. Front. Microbiol. 2020, 10, 3043. [CrossRef] [PubMed]

39. D'Alessandro, B.; Antúnez, K.; Piccini, C.; Zunino, P. DNA extraction and PCR detection of Paenibacillus larvae spores from naturally contaminated honey and bees using spore-decoating and freeze-thawing techniques. World J. Microbiol. Biotechnol. 2007. [CrossRef] 